Ragnhild Lyngved is an associate professor at Sør-Trøndelag University College, in the Faculty of Teacher and Interpreter Education, where she teaches biology. She has participated in the development of the college's master's degree programme in science education. Lyngved has arranged a number of follow-up studies in cloning and molecular biology for teachers in upper secondary schools. Last year she finished her doctoral study at the Department of Biology, Norwegian University of Science and Technology. Her thesis addressed somatic embryogenesis in Cyclamen, with biological investigations and educational aspects of cloning.

\title{
Learning about cloning: developing student knowledge and interest through an interactive, context-based approach
}

\begin{abstract}
Addressing controversial issues in the science classroom demands that students understand the societal aspects of scientific research. A context-based digital teaching unit, "Cloning plants", was designed in order to introduce cloning. The present study analyses students' learning outcomes and the development of their interest in biology from using the unit. The study was conducted among Norwegian biology students aged 17-18. A pretest and posttest design with individual questionnaires and group interviews was chosen. The study shows that use of the unit resulted in a more nuanced understanding of cloning and an increased interest in cloning. About $80 \%$ of the students reported that the realistic context had a positive impact on learning about cloning and $60 \%$ reported that they had learned more about scientific research and societal aspects of research on cloning. Students also reported that the context enhanced their interest in cloning.
\end{abstract}

\section{INTRODUCTION}

Genomics and modern biotechnology are set to become one of the most important scientific and technological revolutions of the twenty-first century (Kirkpatrick, Orvis, \& Pittendrigh, 2002). Hence, the products of modern biotechnology processes such as genetic engineering, DNA testing and cloning will increasingly have an impact on society (Lappan, 2000) and will cause controversies. It is essential that young people have a well-developed scientific understanding of these processes so that they are able to contribute to public debate and make informed personal decisions (Dawson, 2007). Societal aspects of science are often neglected in teaching materials. This aspect is important when it comes to understanding controversial issues such as cloning. In an attempt to provide students with more information about the processes and societal dimensions of cloning, an interactive teaching unit called "Cloning plants" (available at http://viten.no) was developed. This paper presents the results of a small-scale study in which knowledge and interest outcomes of students that used the unit "Cloning plants" was explored.

\section{BACKGROUND}

\section{Cloning' as a controversy in the natural sciences}

Controversial socio-scientific issues, such as cloning, are the kinds of scientific issues typically reported in the media, and are therefore the kind of issues that students are likely to be confronted with in their daily lives (Kolstø, 2001). In itself, cloning is not controversial. Rather, it is its parti- 
cular application to humans that is problematic (Horst, 2005). Because modern society is increasingly called on to address these types of controversial issues, they should be given high priority in science education (Kolstø, 2001).

\section{Cloning as a product, a process and a social institution}

Fewer and fewer young people seem to be interested in science and technology (Kjærnsli, Lie, Olsen, \& Roe, 2007; Osborne \& Dillon, 2008). A possible explanation for this may be that many students find it difficult to see the relevance of science issues. This may be related to the approaches used in teaching science, which traditionally have focused on science as facts and unquestionable knowledge (Kolstø, 2003). According to Sjøberg (2004), science consists of three dimensions: a product, a process and a social institution. In other words, learning about cloning has three aspects: 1) understanding what cloning is, 2) understanding the methods that lead to new theories and knowledge of cloning, 3) knowledge about the institutions and people that carry out research and make use of research results. To enhance students' motivation to learn science and to prepare them to participate in a democratic society, it is important to pay more attention to the last two aspects (Kolstø, 2003; European Commission, 2007).

One important aspect of understanding science is to understand how science develops at its frontiers (Kolstø, 2001). Associated with this is learning about argumentation (Kolstø, 2003; Osborne, 2005). Even though argumentation is considered important in the development of students' understanding of science (von Aufschnaiter, Erduran, Osborne, \& Simon, 2008), activities promoting arguments are not common in science lessons (Mork, 2005).

\section{viten.no as a mediating tool}

A web-based platform called viten.no was used as a mediating tool to introduce the societal aspects of cloning to students. viten.no offers digital teaching programmes in science for secondary school (Mork, 2006a). The main aim for all Viten programmes is for students to learn about the processes and products of science (Jorde, Strømme, Sørborg, Erlien, \& Mork, 2003). The Viten design model stresses the fact that students not only need scientific information when learning science, but also need to be able to apply that knowledge in actual situations, and learn how society deals with scientific information in a broader context (Mork, 2006a).

According to Roschelle, Pea, Hoadley, Gordin and Means (2000), students who participate in computer-connected learning networks show increased motivation, a deeper understanding of concepts, and an increased willingness to deal with difficult questions. Roschelle et al. (2000) claim that technology may enhance the way students learn by supporting the following four fundamental characteristics of learning: active engagement, participation in groups, frequent interaction and feedback, and finally, connections to real-world contexts. All four characteristics advanced by Roschelle et al. (2000) are found in the web-based Viten unit called "Cloning plants". In general, all Viten programmes are designed according to the Scaffolded Knowledge Integration (SKI) principles: make science accessible, make thinking visible, help students learn from each other and promote autonomy and lifelong learning (Linn \& Hsi, 2000; Mork, 2006b). The Viten programmes are all based on theories regarding the social construction of knowledge and the importance of talking about science (Jorde et al., 2003), which are described by Leach and Scott (2003) and Mortimer and Scott (2003). According to this socio-cultural approach, learning and meaning-making are portrayed as originating in social interactions between individuals, or as individuals interact with cultural products that are made available to them in the form of books or other sources (Säljö, 2006).

\section{Context-based approaches}

In order to focus upon the societal aspects of cloning, a context-based approach was chosen in the present Viten unit. Context-based approaches to science teaching are becoming increasingly 
popular, as they are seen as a means of providing pupils with more appealing and more relevant experiences in their science lessons (Ramsden, 1997; Jorde et al., 2003). Despite this agreement, it appears that context-based approaches are rarely used. According to Osborne and Dillon (2008), European students often feel that "science appears as a 'catalogue' of discrete ideas, lacking coherence or relevance, with an over-emphasis on content that is often taught in isolation from the kinds of contexts that might provide essential relevance and meaning". In this way, students may find it difficult to transform scientific knowledge to their own everyday life.

Some courses and curriculum enrichment resources that have been developed to adopt a contextbased approach to science teaching have attracted international attention (Nentwig \& Waddington, 2005). One important influence on these developments was the emergence of the 'Science, Technology and Society (STS)' movement (Solomon \& Aikenhead, 1994). According to Aikenhead (1994), good STS science teaching aims at preparing future scientists and citizens to participate in a society increasingly shaped by research and developments involving science and technology. The present Viten unit shares many of the characteristics of STS teaching.

\section{The Viten unit "Cloning plants"}

The "Cloning plants" teaching unit was released in August 2004, and by September 2008 it had been used by 4615 students and 518 teachers. The content was chosen in accordance with the national curriculum for natural science and biology in upper secondary school (KUF, 1993; KUF,1996). The unit is based on traditional theories about cloning; these are presented in a real life context. The context is a research laboratory and an international research conference on cloning. The approach stresses providing insights into science as a social institution. The unit develops a virtual case, in which students are assigned roles as participants in a summer school located in the research laboratory. As a burglary takes place during the students' stay in the laboratory, they become involved in solving a crime mystery. After the burglary, a valuable powder was found to be missing. According to the police, investigating the crime, there are four suspects, all participants at the international conference on cloning. The police report and other information sources form the base of further investigations carried out by the students. To solve the mystery, they need to: 1) develop their knowledge about cloning, 2) assess the statements of the suspects, 3) carry out analyses of samples of powder in a virtual laboratory. Finally, they present their conclusions, based upon scientific knowledge and argumentation.

One of the objectives of the teaching unit was to show students that cloning can take place at different levels: genes, cells and whole organisms, such as plants, animals and humans. The media is an important source of students' knowledge of biotechnology (Bonfadelli, 2005; Dimopoulos \& Koulaidis, 2003; Shepherd, Barnett, Cooper, Coyle, Moran-Ellis et al., 2007) and the media tend to associate cloning only with animals and humans (Gunter, Kinderlerer, \& Beyleveld, 1998; Horst, 2005). However, cloning has been commonly used for decades to grow potatoes, as one example, and cloning of cells takes place in our body every day. In "Cloning plants", the students also learn about modern techniques in biological research, various aspects of stem cell research and ethical issues. This is expected to contribute to a more in-depth understanding of cloning and stem cells, providing students insights into the role that research laboratories play in creating new scientific knowledge.

\section{Research questions}

The "Cloning plants" unit was designed to introduce the societal aspects of cloning to school science. Since it is difficult to understand these societal aspects without having content-specific knowledge, the aim of this initial study was to see whether a context-based approach improves the needed knowledge base and interest or not:

1. How does the use of the unit affect students' learning outcomes?

2. How does the use of the unit affect students' interest in cloning? 


\section{Methods}

\section{Sample}

The present study was undertaken in five biology classes from three different upper secondary schools in Norway. Four of the classes represented two culturally mixed city schools, while one class was from a small town school. A final sample of 44 students, age 17-18, participated in all written tests: 16 from second grade (2BI) and 28 from third grade (3BI) for a total of 39 girls and 5 boys. Three groups of 4 students each were interviewed. The interview groups were formed by the teachers, using representation of good communicative skills and different levels of knowledge and interest among the students in the group as main criteria.

\section{Experimental design}

All students spent 2-4 hours working through the programme at the Resource Centre for Mathematics, Science and Technology Education at the Norwegian University of Science and Technology. All students worked together in groups at the computer, with two or three students in each group. Discussion and cooperation among the groups was ongoing throughout the session.

Individual questionnaires and a pretest/posttest single group design (Robson, 2002) were chosen so that student achievement before and after use of the teaching programme could be compared. The pretest was conducted the week before and the posttest was performed within one week after the programme's completion.

Semi-structured group interviews (Robson, 2002) were undertaken to obtain supplementary comments and to check whether the students' answers on the paper and pencil tests were in accordance with their oral statements. The group interviews were also specifically used to obtain information about students' interest levels and the effect of the context-based approach, since these two aspects are more difficult to measure with a test. The interviews were carried out the week before and the week after the students' work on the computer, they were tape-recorded and transcribed.

A pilot version of the questionnaire and interview schedule was tested in one class with 17 students in second grade (2BI). Results from the pilot class are not presented.

\section{Achievement tests and interviews}

Ten open-ended questions (Table 1) and seven multiple-choice questions, identical on both tests, were used to compare students' answers at the two points of time. Additionally, the posttest contained six questions that were unique to the test, where alternative statements presented on a Likert scale had to be valued. The students had to reflect on their own knowledge and interest, and explain their achievement and interest with respect to the construction of the programme. The last question was included with the purpose of checking internal consistency within students' judgements.

The multiple choice questions were given code 0 for wrong answers and code 1 for right answers. A coding scheme (Table 1) was developed for open-ended questions, categorising answers from code $0-3$, where 0 represented wrong answers and 3 represented the highest score. To assure accuracy during categorisation, criteria for each question were established. The criteria were chosen partly according to expected answers and partly in the light of the students' actual answers. Criteria for questions 6, 9 and 10 were specifically developed according to the students' answers. The Likert scale used assigned answers a number from $1-6$, where 1 represented "strongly disagree" and 6 "strongly agree". For all questions, missing answers were given code 9. 
Table 1. Coding scheme for open-ended questions identical in all tests. Wrong answers $=0$, Right answers $=1-3$, where 3 is the highest score. Missing answers were coded 9.

\begin{tabular}{|c|c|c|c|c|c|}
\hline \multicolumn{2}{|c|}{ OUESTIONS } & \multirow{2}{*}{\begin{tabular}{l|} 
CODE 0 \\
Wrong answer.
\end{tabular}} & \multirow[b]{2}{*}{$\begin{array}{l}\text { CODE } 1 \\
\text { Examples instead } \\
\text { of explanation, } \\
\text { imprecise, or use } \\
\text { of emotional } \\
\text { words. }\end{array}$} & \multirow{2}{*}{\begin{tabular}{|l|} 
CODE 2 \\
Simple and \\
incomplete \\
explanation.
\end{tabular}} & \multirow[b]{2}{*}{$\begin{array}{l}\text { CODE } 3 \\
\text { Good } \\
\text { explanation, } \\
\text { remembering } \\
\text { that cloning } \\
\text { occurs at } \\
\text { different levels. }\end{array}$} \\
\hline 1 & What is cloning? & & & & \\
\hline 2 & $\begin{array}{l}\text { Can you give any } \\
\text { examples of cloning? } \\
\text { What? }\end{array}$ & $\begin{array}{l}\text { No examples or } \\
\text { wrong answer. }\end{array}$ & 1 example. & 2-3 examples. & $\begin{array}{l}4 \text { or more } \\
\text { examples. }\end{array}$ \\
\hline 3 & What are stem cells? & Wrong answer. & $\begin{array}{l}\text { Examples instead } \\
\text { of explanation, } \\
\text { imprecise, or use } \\
\text { of emotional } \\
\text { words. }\end{array}$ & $\begin{array}{l}\text { Simple and } \\
\text { incomplete } \\
\text { explanation. }\end{array}$ & $\begin{array}{l}\text { Good } \\
\text { explanation, } \\
\text { often used other } \\
\text { biological terms. }\end{array}$ \\
\hline 4 & $\begin{array}{l}\text { How can we use stem } \\
\text { cells? }\end{array}$ & Wrong answer. & $\begin{array}{l}1 \text { area of } \\
\text { application. }\end{array}$ & $\begin{array}{l}2 \text { areas of } \\
\text { application. }\end{array}$ & $\begin{array}{l}3 \text { or more areas } \\
\text { of application. }\end{array}$ \\
\hline 5 & $\begin{array}{l}\text { Do you know any } \\
\text { methods that can } \\
\text { be used to clone } \\
\text { animals? If yes, } \\
\text { explain these } \\
\text { methods. }\end{array}$ & $\begin{array}{l}\text { No knowledge } \\
\text { about methods } \\
\text { or wrong } \\
\text { answer. }\end{array}$ & $\begin{array}{l}1 \text { method, } \\
\text { no or wrong } \\
\text { explanation. }\end{array}$ & $\begin{array}{l}\text { 1-2 methods } \\
\text { and correct } \\
\text { explanation of } \\
\text { at least one of } \\
\text { the methods. }\end{array}$ & $\begin{array}{l}3 \text { or more } \\
\text { methods } \\
\text { and correct } \\
\text { explanations. }\end{array}$ \\
\hline 6 & $\begin{array}{l}\text { Can you name any } \\
\text { plants that are able } \\
\text { to naturally clone } \\
\text { themselves? Explain } \\
\text { how. }\end{array}$ & $\begin{array}{l}\text { Wrong } \\
\text { answer and } \\
\text { explanation. }\end{array}$ & $\begin{array}{l}\text { 1-2 examples, } \\
\text { no or wrong } \\
\text { explanations, } \\
\text { or just an } \\
\text { explanation. }\end{array}$ & $\begin{array}{l}\text { 1-2 examples } \\
\text { and simple } \\
\text { explanations. }\end{array}$ & $\begin{array}{l}2 \text { or more } \\
\text { examples } \\
\text { and good } \\
\text { explanations. }\end{array}$ \\
\hline 7 & $\begin{array}{l}\text { How can we use } \\
\text { plant hormones? }\end{array}$ & Wrong answer. & $\begin{array}{l}1 \text { area of } \\
\text { application. }\end{array}$ & $\begin{array}{l}2-3 \text { areas of } \\
\text { application. }\end{array}$ & $\begin{array}{l}4 \text { or more areas } \\
\text { of application. }\end{array}$ \\
\hline 8 & $\begin{array}{l}\text { What do you think } \\
\text { about cloning? }\end{array}$ & $\begin{array}{l}\text { No thoughts } \\
\text { about cloning. }\end{array}$ & \begin{tabular}{|l|} 
Little \\
understanding, \\
imprecise \\
expression, use of \\
single emotional \\
words. \\
\end{tabular} & $\begin{array}{l}\text { Some interest } \\
\text { could be seen, } \\
\text { a personal } \\
\text { opinion was } \\
\text { given. }\end{array}$ & $\begin{array}{l}\text { Obvious interest, } \\
\text { reflection, was } \\
\text { able to see the } \\
\text { case from more } \\
\text { than one side. }\end{array}$ \\
\hline 9 & $\begin{array}{l}\text { What kind of risks } \\
\text { can be associated } \\
\text { with cloning? Give } \\
\text { reasons for your } \\
\text { answer. } \\
\end{array}$ & $\begin{array}{l}\text { No risk or } \\
\text { reasons. }\end{array}$ & $\begin{array}{l}\text { 1-2 examples, } \\
\text { no or wrong } \\
\text { explanations. }\end{array}$ & $\begin{array}{l}\text { 1-2 examples } \\
\text { and simple } \\
\text { explanations. }\end{array}$ & $\begin{array}{l}2 \text { or more } \\
\text { examples } \\
\text { and good } \\
\text { explanations. }\end{array}$ \\
\hline 10 & $\begin{array}{l}\text { Do you remember } \\
\text { having seen, heard } \\
\text { or read something } \\
\text { about cloning in the } \\
\text { news? Explain what it } \\
\text { was about and what } \\
\text { you remember. }\end{array}$ & $\begin{array}{l}\text { Remembered } \\
\text { no cases or } \\
\text { cases that } \\
\text { dealt with } \\
\text { something } \\
\text { other than } \\
\text { cloning. }\end{array}$ & $\begin{array}{l}\text { 1-2 examples } \\
\text { (often Dolly), no } \\
\text { explanation. No } \\
\text { interest shown. }\end{array}$ & $\begin{array}{l}\text { 1-3 examples, } \\
\text { simple } \\
\text { explanation. } \\
\text { Moderate } \\
\text { interest } \\
\text { shown. }\end{array}$ & $\begin{array}{l}2 \text { or more } \\
\text { examples, } \\
\text { expanded } \\
\text { explanations. } \\
\text { Obvious interest } \\
\text { in the news. }\end{array}$ \\
\hline
\end{tabular}


The group interviews each lasted approximately 30 minutes. The questions focused on the students' knowledge of and interest in cloning, research in general, research in cloning, as well as their appreciation of the context-based approach. The majority of the questions were the same before and after the computer work, but the post interview also contained three questions about knowledge gained, interest and the context. To ensure that all students in the interview groups participated in the interview, a direct request was given each of them during most of the questions. The interviews were analysed using ad hoc meaning generation (Kvale, 1996).

Research question 1 was addressed by 10 open-ended questions, 11 multiple choice questions, and the group interviews. Research question 2 was addressed by 3 open-ended questions, 4 multiple choice questions, and the group interviews. The importance of a context-based approach in students' learning and interest was highlighted in 5 multiple choice questions and the group interviews.

\section{Statistical analysis}

Statistical tests were performed using SPSS 15.0 (SPSS Inc., 2006). Student numbers allowed comparisons between pretest, posttest and interviews.

\section{Reliability of the questionnaire}

Cronbach's alpha calculated for the 17 questions common to both tests (questions 1 - 17) showed high internal consistency between items $(\alpha=.849)$. Appropriate reliability was also found when the Likert scale questions were included and the items were split with regard to the themes for the two research questions: knowledge $(\alpha=.815,20$ items $)$ and interest ( $=.651,7$ items). Items that were meant to explain the effect of the different parts of the programme were not included in these calculations. The Cronbach's alpha for interest is relatively low, and some caution must be made when interpreting these data.

\section{RESULTS}

\section{Students' knowledge of cloning}

In an attempt to see how the context-based approach affected students' learning outcomes, achievement tests were used to measure students learning gains. Statistical tests show that the score on the posttest was significantly higher than on the pretest $(\mathrm{p}<.001)$ (Figure 1). Only 6 students had 5 or more correct answers on multiple-choice questions in the pretest, while 21 students had 5-7 correct answers in the posttest (maximum score $=7$ ) (Figure 2).

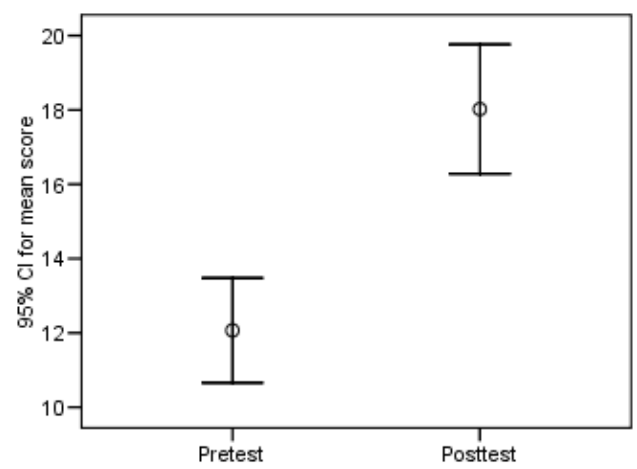

Figure 1. Results from achievement tests, given as 95\% confidence intervals (CI) for mean score. $N=44$. Maximum score $=37$. Data include results from the questions common to both tests: 10 open-ended questions and 7 multiple-choice questions. 


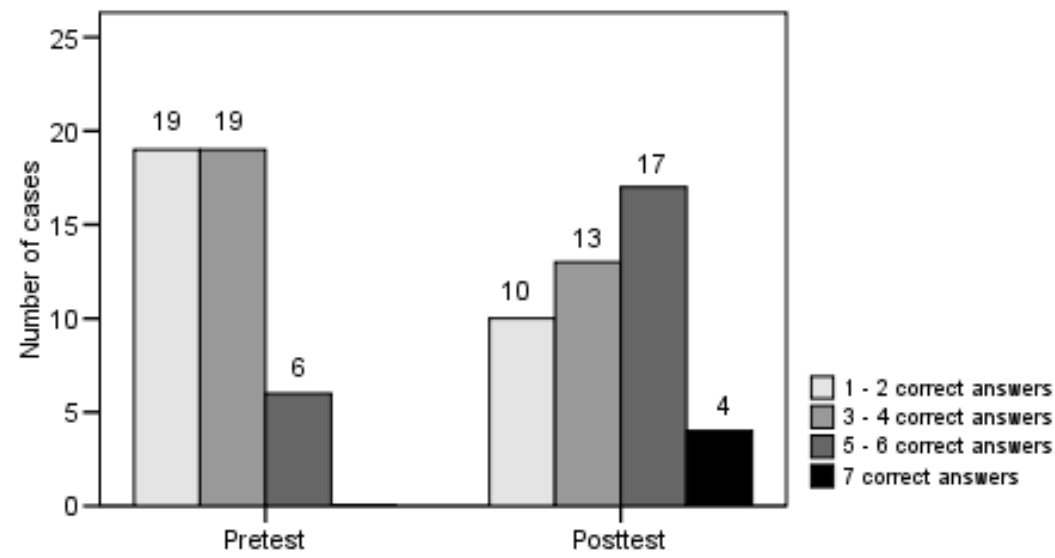

Figure 2. Student scores on multiple-choice questions on the two tests. $N=44$.

Maximum score $=7$.

In order to understand more about students' responses to the tests and the data behind Figures 1 and 2, some examples of individual answers will be presented (Examples $1-6$ ). These examples are representative for a large group of students. There was a qualitative difference between the students' answers to open-ended questions before and after the work with the programme. Example 1 and 2 show that the students associated cloning with "copying" something and that "Dolly the sheep" was the familiar example before they worked on the programme. Afterwards they knew that cloning occurs at different levels.

\begin{tabular}{|c|c|}
\hline \multicolumn{2}{|c|}{$\begin{array}{l}\text { Example 1: } \\
\text { Question } 1 \text { What is cloning? }\end{array}$} \\
\hline Pretest & Posttest \\
\hline Student 14 & \\
\hline $\begin{array}{l}\text { To copy DNA. } \\
\text { Student } 20\end{array}$ & Copying of a gene, a cell, a plant or an animal. \\
\hline $\begin{array}{l}\text { When you make two } \\
\text { identical individuals. } \\
\text { Copying. }\end{array}$ & $\begin{array}{l}\text { Copying of a living individual or a part of a living individual, such that the } \\
\text { copy becomes identical. Gets the same hereditary material. Cloning of hu- } \\
\text { mans, animals, plants, cells, genes. }\end{array}$ \\
\hline
\end{tabular}

\begin{tabular}{ll}
\hline $\begin{array}{l}\text { Example 2: } \\
\text { Question } 2 \text { Can you give any examples of cloning? Which? }\end{array}$ \\
\hline $\begin{array}{l}\text { Pretest } \\
\text { Student } 14 \\
\text { Dolly the sheep }\end{array}$ \\
$\begin{array}{l}\text { Student } 21 \\
\text { Dolly the sheep }\end{array}$ \\
$\begin{array}{l}\text { Cloning of Dolly the sheep. Some people think that humans have been } \\
\text { cloned as well, but there's no evidence of that. Of course a lot of other ani- } \\
\text { mals, many invertebrates have been cloned. Plants: The strawberry plant } \\
\text { has natural cloning - runners. The potato plant has natural cloning } \\
\text { - cuttings. }\end{array}$ \\
\hline
\end{tabular}

As part of the goal to increase students' knowledge of cloning, it was desirable to increase the students understanding of stem cells. Example 3 shows answers from two students who achieved this goal. 


\title{
Example 3:
}

Question 3 What are stem cells?

\section{Pretest}

\section{Posttest}

\section{Student 3}

I don't know.

Stem cells are cells that theoretically can develop into all cell types in a newborn individual because they are not specialized.

\section{Student 46}

Contain the DNA?

Stem cells are the "original" cells. A foetus consists of only stem cells. Some stem cells can develop into any other kind of cells (totipotent), while others are specialized.

Example 4 and 5 show answers that illustrate increased knowledge of animal and plant cloning.

\section{Example 4:}

Question 5 Do you know any methods that can be used to clone animals? If yes, explain these methods!

Pretest Posttest

Student 15

No

\begin{abstract}
Yes, I remember a part of the explanation of how "Dolly" was made. An ordinary body cell from the animal that was to be cloned was placed into a "glass". Then an egg cell from a donor sheep was taken out. The nucleus from this egg cell was removed, and the "rest" of the cell "I believe" was placed in the glass together with the ordinary cells. Then they "melted" together and afterwards it became an embryo. This was then placed into the uterus of the sheep that would carry the lamb.
\end{abstract}

\footnotetext{
Example 5:

Question 6 Can you name any plants that are able to clone themselves naturally? Explain how!

\section{Pretest
Student 14 \\ Pretest
Student 14}

No

\section{Posttest}

Potatoes and strawberries. The potato plant makes potatoes under the soil with the same cells as itself. Then the potato germinates and a new potato plant with the same genes grows up. The strawberry plant shoots up a stem that attaches to the soil and makes a new plant.
}

\section{STUDENT 46}

I don't remember the name. Releases seeds that are identical with Potatoes, strawberry plants. If you set a potato in the soil the bulbs of the potatoes will grow and develop new potatoes. This happens without the plant. 
The students' assessment of their learning outcomes was in accordance with the test results. The majority, 79.5\%, agreed (4 - 6 on the Likert scale from $1-6)$ that the programme had given them more knowledge about cloning, and 60\% agreed that they knew more about the way researchers work. In addition, 72.5\% agreed that they had improved their understanding of ethical issues related to cloning and the research in cloning. The most frequently selected reasons given for their increased knowledge were simple and good explanations (88.2\% agreed), good figures and animations (94.1\% agreed), and good questions and exercises (97.1\% agreed). In general, all students were positive to these three aspects of the programme, whether they improved their knowledge or interest or not. The figures and animations were particularly valued as instructive. This was the explanation with highest mean score: the mean score was 5.21 as the reason for knowledge gain and 5.07 as the reason for increased interest, with 6 as the maximum possible score. One student explained her increase in knowledge during the interview question in this way:

It was the laboratory analyses that were in a way exciting, because it was something that you had to do. It wasn't only reading or seeing a movie, you worked with it yourself. That was maybe what I found exciting. What I learned most from, maybe. (Student 12)

\section{Students' interest in cloning}

To see how the "Cloning plants" unit affected students' interest in the controversy around cloning, achievement tests and interviews were used. In general, the analyses showed that their interest was a little higher in the posttest than in the pretest $(\mathrm{p}=.033)$. Dividing the students into two groups, depending on their interest score on the pretest (low score $=0-3$ points, high score $=4-9$ points, maximum score $=9$ ) showed that students with lower scores enhanced their interest significantly more than those with higher scores $(\mathrm{p}<.001)$ (Figure 3$)$. Among the students with lower scores, $45.4 \%$ increased their interest score by 2 or 3 points, while the most common improvement among students with higher scores was 1 point, and representing $31.8 \%$ of students. In addition, a positive correlation was found between knowledge and interest $(\mathrm{r}=.748, \mathrm{p}<.001)$ and between knowledge increase and interest increase $(\mathrm{r}=.678, \mathrm{p}<.001)$ (Figure 4).

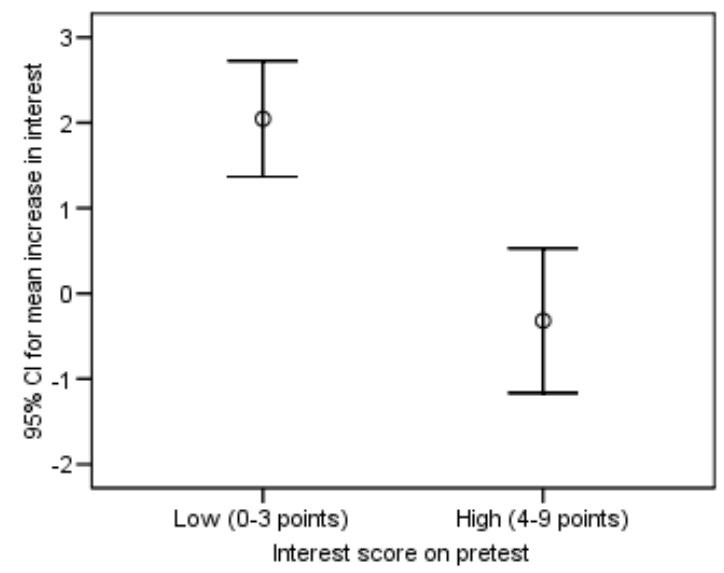

Figure 3. Increase in interest from pretest to posttest, given as 95\% confidence intervals (CI) for mean, in relation to interest level before using the "Cloning plants" unit. The students were divided into two groups with regard to their interest level in the pretest: low (score 0-3 points on 3 questions, $N=22$ ) and high (score 4-9 points on 3 questions, $N=22$ ). 


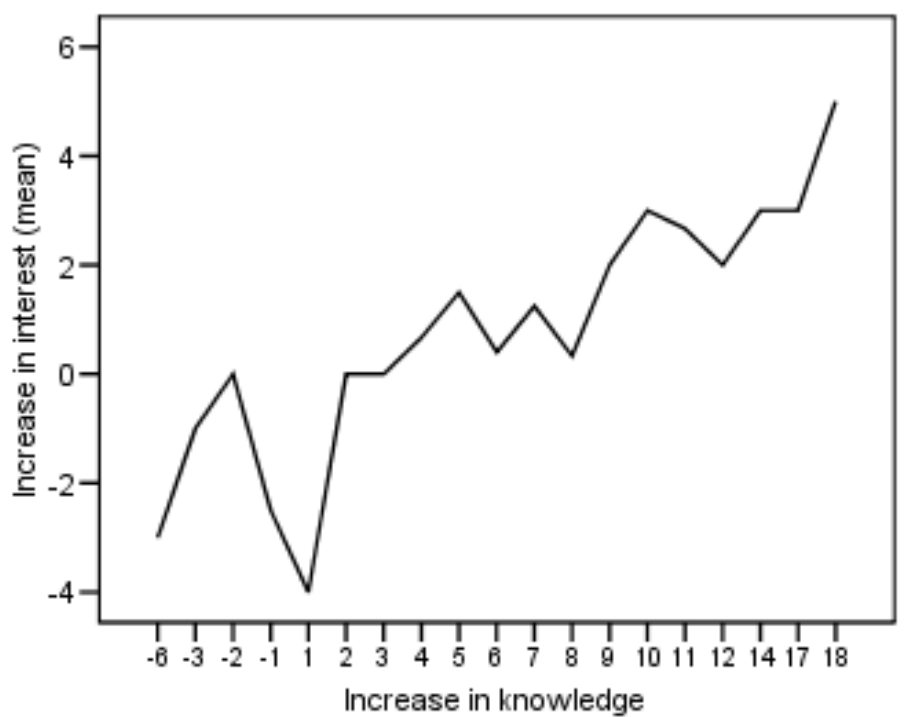

Figure 4. Increase in interest (increased score on 3 questions from pretest to posttest, maximum score $=9$ ) in proportion to increase in knowledge (increased score on 17 questions from pretest to posttest, maximum score $=37)$. $N=44$.

Two answers that illustrate increased interest and a better understanding of cloning are given in Example 6.

\section{Example 6:}

Question 8 What do you think about cloning?

\section{Pretest}

\section{Student 4}

Idon't like it. What do we need 2 copies of a thing for? But if it can be used for something valuable it may be good.

\section{Student 21}

I think it is ethically indefensible to clone things.

\section{Posttest}

I am actually really against cloning. I think it is to tamper with nature, it doesn't make that thing real. I think that mostly about cloning humans and animals. Plants propagate themselves as well, but we don't have a very close relationship to plants, compared to animals and human. It is fine if cloning manages to find treatments for serious diseases.

Cloning is an exciting field, where much is still unanswered. Cloning can be useful in regards to medicine, by cloning cells and organs. We can make plants that are extra viable! But it raises many ethical questions.

The majority of the students, $72.7 \%$, indicated that their interest in cloning had increased after working through "Cloning plants", and 60\% agreed that they became more interested in the way researchers work. The interviews showed, however, that students were quite enthusiastic and interested in cloning as a subject even before they worked through the programme, especially with regard to animal and human cloning. For example one student said:

If something comes up in the media about cloning, I would actually read it no matter if it was before or after I spent time with this programme. But now, however, I actually risk understanding what is written...compared to earlier. In this way I have learned something. (Student 12) 


\section{The importance of a context-based approach in students' learning and interest}

The aim of this study was to see if a context-based approach would either facilitate or complicate scientific learning and interest. Therefore the students were asked to clarify whether or not they thought their knowledge and interest had improved. Six alternative statements presented on a Likert scale were used to assess this question. Fully $79.4 \%$ of the students who stated that they had learned about cloning claimed that the realistic context had a positive effect on their learning, and $81.8 \%$ believed that the use of the mystery as a teaching tool had positive effect on their learning. The majority of the students that felt their interest had improved also agreed that the context and mystery had a positive effect. Out of the students that disagreed about greater knowledge or interest, $88.9 \%$ and $100 \%$ disagreed (1-3 on the Likert scale from 1-6) that the context-based approach was the reason for less knowledge gain and less interest improvement, respectively. Among all the students, $16.6 \%$ claimed that the contextual case distracted their attention from gaining knowledge of and/or interest in cloning. The following quotations from interviews illustrate the impact of the context-based approach. This first student tries to explain why she actually learned something from the programme:

It is a bit funny. You have to use the knowledge you get while you are sitting there, you have to use it for something. In a way, you have to know it in practice. It is not often you need to know something in practice when you are in a classroom, sort of. Then you learn something about how it works, and then you just have the one example in the textbook, for example. You don't learn to use it outside. I think it was fun that we had to use our knowledge...that the whole setting became fun, sort of. (Student 22)

Two other statements show that the students may approach a subject more easily if they involve themselves or reduce their own distance to the subject or context:

It was interesting that it was younger researchers that were doing something. It seemed like it was a younger researcher that kept it going and that it was new. Not only old fellows with long, white beards, glasses and big stomachs. (Student 22)

It was something new to me and was a different way of learning things that I have never tried before. This makes it even more interesting. That the situation was so in touch with reality as it was, that no aliens and things like that were included. It was so concrete, and you were in a surrounding that you knew pretty well, you were in Trondheim city, where you live. It was understandable. (Student 22)

Before they tried the "Cloning plants" unit, the students were asked if they thought it was interesting to learn how researchers work. The following answers indicate that these societal aspects of science seldom appear in science teaching:

Actually I haven't heard anything about it, so I can't tell you much. (Student 21)

I think it is interesting to hear how researchers work, because I have no idea how they do it. (Student 22)

I think it is interesting. The way they do it and why they do it. (Student 16)

After their work on the unit, the students were asked if they thought the cloning issue had become more interesting when they had learned about it through researchers. Three answers are given below:

After we were included, and had seen that researchers are working with it and that a really large conference was about it and that it actually is real....A bit more interesting because of that. (Student 32) 
We are certainly not experts in cloning. Anyway we managed to use the little knowledge we had and what we had access to. We manage to solve the mystery about it. So, I thought it was a little fun. You didn't need to be a researcher to understand it, in a way. To figure out things, think nearly in the same way as the researchers have to. That was fun. (Student 22)

I didn't know much about how researchers work. Now I have more insights into how it happens... it is easier to learn about cloning through the researcher, because it is more trustworthy. After all, they are people that have worked a lot with it and know what they know, in a way. (Student 15)

\section{Discussion}

\section{Students' knowledge of cloning}

One goal for using the "Cloning plants" unit was to help students to understand cloning so they could make informed personal decisions and participate in public debates. According to von Aufschnaiter et al. (2008), it is necessary to consider the nature of and extent of students' contentspecific knowledge prior to asking them to engage in argumentation. The results from this study's achievement tests show that the students actually improved their scientific knowledge significantly after working through the programme (Figures 1 and 2). The student evaluations also indicated that their understanding of scientific research improved. In general, the students gave more elaborate answers in the posttest. Our results are in accordance with evaluations of the other Viten programmes, Earth Processes, Wolves in Norway and Radioactivity (Jorde et al., 2003; Mork \& Jorde, 2004; Mork, 2006b), in which differences found between pre and posttest results were striking.

One objective of our programme was to show that cloning occurs at different levels, from genes, to cells, to whole organisms. Examples 1 and 2 show that many students associated cloning with "copying" and "Dolly the sheep" before they tried the programme. This is similar to what was found among Australian high school students. According to Dawson (2007), these students associated cloning with 'copying' or 'duplicating' something. The most common example of cloning for all year groups was "sheep" or "Dolly the sheep". Posttest answers in our study indicated that the "Cloning plants" unit succeeded in imparting the different levels of cloning (Example 1 and 2, answers to posttest), especially with respect to plants.

Some students appeared to be confused about the difference between cloning and genetic engineering $^{2}$. One of our students explained that "Cloning is to make identical organisms by tampering with $D N A$ " and animals can be cloned "by changing dna in the animal" (Student 40). Other students mentioned "Cloning of tomatoes, so that they can last longer" (Student 28), "Cloning food" (Student 22) and "Belgian blue" as examples. The tomatoes are clearly the genetically modified Flavr Savr tomatoes. The other examples may be linked to the fact that about $25 \%$ of Europeans claim that "Genetically modified animals are always bigger than ordinary ones" (Gaskell, Allansdottir, Allum, Corchero, Fischler et al., 2006). Dawson and Schibeci (2003) also reported that 13.5\% of their Australian students gave food as an example of cloning. Dawson and Schibeci (2003) found that $28.7 \%$ of 15 -year-old students from Australia were confused about the difference between cloning and genetic engineering, believing that Dolly the sheep was genetically engineered.

The teacher resources that come with the "Cloning plants" unit suggest that students need $4-5$ lesson hours to complete the programme. It is also suggested that these lessons be divided between two or more days. For practical reasons the teachers involved in this study allocated from $2.5-4.5$ hours (about $3-6$ lesson hours) concentrated during only one day. This time was also spent on information, breaks and concluding remarks. Due to the limited time allocated, not all students completed the programme, particularly the closing activity, which involved writing and presenting a summary of their findings, with scientific arguments and evidence in focus. Additionally, the teacher resources recommended holding a debate after the unit is finished. This was not done by 
any of the classes before the posttest. Spending more time with these tasks might have influenced student learning outcomes. During interviews students pointed out the high amount of scientific content and hence a need for two or more days to complete the programme.

\section{Students' interest in cloning}

One aim of the "Cloning plants" unit was to enhance student interest in cloning. Our study showed that students with little interest in cloning enhanced their interest after working through the unit (Figure 3), and a positive correlation was found between increased knowledge and increased interest (Figure 4). This correlation is in accordance with the findings of Reeve and Hakel (2000) and Bonfadelli (2005). There is some disagreement in the literature, however, about the causal link and whether it is affective factors, such as interests and attitudes, or achievement that is the dependent variable (Osborne, Simon, \& Collins, 2003). According to Harms (2002), an interest in the particular topic to be learned is very important in determining learning outcomes. Earlier experiences and achievements have also been shown to serve as major influences on academic interest or attitudes (Nergård, 2008). Supplementary investigations are necessary to further analyse correlations as shown in our study.

Approximately half of the students were quite interested in cloning before this study started and did not enhance their interest (Figure 4). Cloning is the kind of subject that people are likely to be concerned about. According to Gaskell et al. (2006), 71\% of the European public "definitely would" or "probably would" read articles or watch TV programmes on biotechnology, including cloning. Moreover, the students in our study have chosen to study biology in upper secondary school, suggesting that they have a special interest in issues related to biology.

The majority of our students achieved a more nuanced picture of cloning. Initially many students associated cloning with reproductive cloning and saw no real benefits, as was found by Shepherd et al. (2007). After their exposure to the material, the majority were able to describe both positive and negative aspects of cloning. The students perceived cloning as acceptable if the techniques were useful with regard to medicine and treatment of diseases, similar to what Calnan, Montaner and Horne (2005) and Sáez, Niño and Carretero (2008) found in their studies. Nevertheless, the majority of our students considered the cloning of animals and humans as ethically indefensible. This is similar to the findings from Cavanagh, Hood and Wilkinson (2005) in a study of Australian secondary school students' views of biotechnology.

\section{The importance of a context-based approach in students' learning and interest}

In the light of our study, which featured a small sample and no comparison with a more traditional approach to the subject, it is not possible to conclude whether the increase in knowledge and interest were caused by the interactive and context-based approach or just by the hours the students spent with the subject. Student answers indicate, however, that there might be a connection between their increased knowledge and interest and the context-based approach. Among the students who improved their knowledge, about $80 \%$ believed they learned more because of the context and the mystery, while five students actually were distracted by the contextual case, and thus were prevented from learning about cloning, plants and regulations. Statements from interviews indicate that the focus on societal aspects of cloning enhanced students' interest in research and cloning. Wierstra (1984) and Ramsden (1994, 1997) also found some benefits associated with a context-based approach in terms of stimulating pupils' interest in science and motivation in lessons.

\section{Evaluation of the experimental design}

The pretest/posttest single group design is widely used (Robson, 2002). According to Robson (2002), however, our design is considered to be quasi-experimental, because no control group of students following a more traditional approach was included. No control group was used because, 
firstly, it is difficult to find science classes that can act as reliable control groups. Making such arrangements would represent considerable challenges in terms of involving teachers and students in a fixed design. Secondly, the lack of a control group was compensated by assess to additional information from the interviews, providing detailed information on the significance of different aspects and parts of the teaching unit in development of knowledge and interest.

The pretest in itself might affect results. Possible validity threats, including history and maturation between measures, should also be taken into consideration. Since the study included a limited number of respondents, generalizations have been avoided. Group interviews may be an effective method for gathering information, but the students are often active in different parts of the interview, and it may be difficult to judge the progress of individuals. Despite these facts, our study may be of value as part of a wider study, or as a pilot phase for later experimentation. The results of our study demonstrate some trends and patterns which may be valuable to further research into the field of the Viten programmes and context-based teaching materials that focus on societal aspects of science.

\section{CONCLUSION}

If one is to understand the scientific issues surrounding cloning, one has to understand the body of knowledge that science has generated on cloning ("products"), the ways in which research in cloning takes place ("processes") and the societal aspects of the development of knowledge about cloning ("social institutions"). Traditionally, science teaching has focused on science as facts and unquestionable knowledge, but this sole focus seems to make young people lose interest in science. Furthermore, school science does not prepare students to understand scientific research and to actively engage in debates they encounter in the media and in society as a whole. To give students an overall and realistic picture of science, and to prepare them to understand the scientific dimensions of controversies, they need to learn how knowledge is generated and how it is accounted for. This can be achieved by introducing context-based approaches that focus on research. If the subject is to be of interest for students, they need to see its relevance. By working through the interactive and context-based "Cloning plants" unit, a majority of the students increased their understanding of and interest in scientific research. The participants improved their knowledge of cloning and obtained a more nuanced picture of this controversial issue. Students that initially showed low interest increased their interest in cloning.

Further research should focus upon true experimental designs. To be able to document the effects of learning from the interactive and context-based approach, the students' scores should be compared to students who receive traditional instruction only. Furthermore, the long-term effect of students' learning outcomes should be investigated for the two approaches. It might also be interesting to study whether and to what extent the students' skills are transferable to other cases - whether the two approaches foster higher-order thinking skills, and whether interactive and context-based learning materials alone would contribute to foster scientific and technological literacy.

\section{ACHNOWLEDGEMENTS}

The author would like to acknowledge cooperative work with Wenche Erlien, Øystein Sørborg, Peter van Marion, Tor-Henning Iversen and Alex Strømme during the development and testing of the Viten programme. I would also like to thank Ole Johan Borge for important comments on the cloning theory in the programme, the teachers who participated with their classes and Peter van Marion for valuable comments on the manuscript. The project was financially supported by the Research Council of Norway (Project no. 157603/440), the ALLFORSK foundation (Project no. 1149126) and the Norwegian University of Science and Technology. 


\section{REFERENCES}

Aikenhead, G. (1994). What is STS Science Teaching? In J. Solomon \& G. Aikenhead (Eds.), STS Education. International perspectives on reform (pp. 47-59). New York: Teachers College Press.

Bonfadelli, H. (2005). Mass media and biotechnology: Knowledge gaps within and between European countries. International journal of public opinion research, 17(1), 42-62.

Calnan, M., Montaner, D., \& Horne, R. (2005). How acceptable are innovative health-care technologies? A survey of public beliefs and attitudes in England and Wales. Social Science \& Medicine, 60, 1937-1948.

Cavanagh, H., Hood, J., \& Wilkinson, J. (2005). Riverina high school students' views of biotechnology. Electronic Journal of Biotechnology, 8(2), 121-127.

Dawson, V. (2007). An Exploration of High School (12-17 Year Old) Students' Understanding of, and Attitudes Towards Biotechnology Processes. Research in Science Education, 37, 59-73.

Dawson, W., \& Schibeci, R. (2003). Western Australian school students' understanding of biotechnology. International Journal of Science Education, 25(1), 57-69.

Dimopoulos, K., \& Koulaidis, V. (2003). Science and Technology Education for Citizenship: The Potential Role of the Press. Science Education, 87, 241-256.

European Commission. (2007). Science Education NOW: A Renewed Pedagogy for the Future of Europe. High Level Group on Science Education, Directorate-General for Research, Directorate L - Science, Economy and Society. EUR 22845.

Gaskell, G., Allansdottir, A., Allum, N., Corchero, C., Fischler, C., Hampel, J. et al. (2006). Europeans and Biotechnology in 2005: Patterns and Trends. Eurobarometer 64.3. A report to the European Commission's Directorate-General for Research.

Gunter, B., Kinderlerer, J., \& Beyleveld, D. (1998). Teenagers and Biotechnology: A Survey of Understanding and Opinion in Britain. Studies in Science Education, 32, 81-112.

Harms, U. (2002). Biotechnology Education in Schools. Electronic Journal of Biotechnology, 5(3), 205-211.

Horst, M. (2005). Cloning sensations: mass mediated articulation of social responses to controversial biotechnology. Public Understanding of Science, 14, 185-200.

Jorde, D., Strømme, A., Sørborg, Ø., Erlien, W., \& Mork, S. M. (2003). Virtual Environments in Science, Viten.no. Skriftserie for Forsknings- og kompetansenettverk for IT i utdanning (ITU), Universitetet i Oslo. Oslo: Unipub.

Kirkpatrick, G., Orvis, K. S., \& Pittendrigh, B. (2002). Genomic Analogy Model for Educators (GAME): A teaching model for biotechnology and genomics education. Journal of Biological Education, 37(1), 31-35.

Kjærnsli, M., Lie, S., Olsen, R. V., \& Roe, A. (2007). Tid for tunge løft. Norske elevers kompetanse i naturfag, lesing og matematikk i PISA 2006. Oslo: Universitetsforlaget.

Kolstø, S. D. (2001). Scientific Literacy for Citizenship: Tools for Dealing with the Science Dimension of Controversial Socioscientific Issues. Science Education, 85(3), 291-310.

Kolstø, S. D. (2003). Et allmenndannende naturfag. Fagets betydning for demokratisk deltakelse. In D. Jorde \& B. Bungum (Eds.), Naturfagdidaktikk. Perspektiver, Forskning, Utvikling (pp. 59-85). Oslo: Gyldendal Akademisk.

KUF. (1993). Loereplan for videregående opploering (R94), Naturfag, Felles allmennt fag for alle studieretninger. Kirke-, utdannings- og forskningsdepartementet, Oslo.

KUF. (1996). Lcereplan for videregående opplaering (R94), Biologi, Studieretningsfag $i$ studieretning for allmenne, økonomiske og administrative fag. Kirke-, utdannings- og forskningsdepartementet, Oslo.

Kvale, S. (1996). Interviews : an introduction to qualitative research interviewing. Thousand Oaks: Sage.

Lappan, G. (2000). A vision of learning to teach for the $21^{\text {st }}$ century. School Science and Mathematics, 100, 319-325.

Leach, J., \& Scott, P. (2003). Individual and Sociocultural Views of Learning in Science Education. Science \& Education, 12, 91-113.

Linn, M. C., \& Hsi, S. (2000). Computers, Teachers, Peers. Science Learning Partners. New Jersey: Lawrence Erlbaum Associates.

Mork, S. M. (2005). Argumentation in science lessons: Focusing on the teacher's role. NorDiNa, $1,17-30$. 
Mork, S. M. (2006a). viten.no - digital teaching programs in science education. NorDiNa, 3.

Mork, S. M. (2006b). ICT in Science Education. Exploring the Digital Learning Materials at viten. no. Series of dissertations submitted to the Faculty of Education, University of Oslo, No. 53.

Mork, S. M., \& Jorde, D. (2004). We Know they Love Computers, but do they Learn Science? Using Information Technology for Teaching about a Socio-scientific Controversy. Themes in Education, 5(1), 69-100.

Mortimer, E. F., \& Scott, P. H. (2003). Meaning Making in Secondary Science Classrooms. Maidenhead: Open University Press.

Nentwig, P., \& Waddington, D. (2005). Making it relevant. Context based learning of science. Münster: Waxmann.

Nergård, T. (2008). Undervisningsvariabler og elevenes holdninger til naturfag. In Marion, P. van \& Strømme, A. (Eds.), Biologididaktikk (pp. 58-76). Kristiansand: Høyskoleforlaget.

Osborne, J. (2005). The role of argument in science education. In K. Boersma, M. Goedhart, O. de Jong \& H. Eijkelhof (Eds.), Research and the Quality of Science Education (pp. 367-380). Dordrecht: Springer.

Osborne, J. \& Dillon, J. (2008). Science Education in Europe: Critical Reflections. A Report to the Nuffield Foundation. The Nuffield Foundation, London.

Osborne, J., Simon, S., \& Collins, S. (2003). Attitudes towards science: a review of the literature and its implications. International Journal of Science Education, 25(9), 1049-1079.

Ramsden, J. M. (1994). Context and activity-based science in action. Some teachers' views of the effects on pupils. School Science Review, 75(272), 8-14.

Ramsden, J. M. (1997). How does a context-based approach influence understanding of key chemical ideas at 16+? International Journal of Science Education, 19(6), 697-710.

Reeve, C. L., \& Hakel, M. D. (2000). Toward an Understanding of Adult Intellectual Development: Investigating Within-Individual Convergence of Interest and Knowledge Profiles. Journal of Applied Psychology, 85(6), 897-908.

Robson, C. (2002). Real world research. Oxford: Blackwell Publishing Ltd.

Roschelle, J. M., Pea, R. D., Hoadley, C. M., Gordin, D. N., \& Means, B. M. (2000). Changing How and What Children Learn in School with Computer-Based Technologies. The future of children, 10(2), 76-101.

Sáez, M. J., Niño, A. G., \& Carretero, A. (2008). Matching Society Values: Students' views of biotechnology. International Journal of Science Education, 30(2), 167-183.

Säljö, R. (2006). Loering og kulturelle redskaper. Om læreprosesser og den kollektive hukommelsen. Oslo: Cappelen Akademisk Forlag.

Shepherd, R., Barnett, J., Cooper, H., Coyle, A., Moran-Ellis, J., Senior, V. et al. (2007). Towards an understanding of British public attitudes concerning human cloning. Social Science $\&$ Medicine, 65, 377-392.

Sjøberg, S. (2004). Naturfag som allmenndannelse - en kritisk fagdidaktikk. Oslo: Gyldendal Akademisk.

Solomon, J., \& Aikenhead, G. (1994). STS Education. International perspectives on reform. Ways of Knowing in Science Series. New York: Teachers College Press.

von Aufschnaiter, C., Erduran, S., Osborne, J.,\& Simon, S. (2008). Arguing to Learn and Learning to Argue: Case Studies of How Students' Argumentation Relates to Their Scientific Knowledge. Journal of Research in Science Teaching, 45(1), 101-131.

Wierstra, R. (1984). A Study on Classroom Environment and on Cognitive and Affective Outcomes of the PLON-Curriculum. Studies in Educational Evaluation, 10(3), 273-282.

\section{Notes}

${ }^{1}$ Cloning is here defined as the process that creates a copy of some biological entity (a DNA sequence, a cell or an organism) (http://www.thefreedictionary.com/cloning).

${ }^{2}$ Genetic engineering is here defined as the process of altering the genetic material of a cell or organism (http://www.geron.com/technology/glossary/screening.aspx). 